Article

\title{
Efficiency of Novel Antimicrobial Coating Based on Iron Nanoparticles for Dairy Products' Packaging
}

\author{
Marta Ligaj *(1), Mariusz Tichoniuk $(\mathbb{D}$, Ryszard Cierpiszewski@ and Zenon Foltynowicz \\ Department of Non-Food Products Quality and Packaging Development, Institute of Quality Science, \\ Poznań University of Economics and Business Al. Niepodległości 10, 61-875 Poznań, Poland; \\ mariusz.tichoniuk@ue.poznan.pl (M.T.); ryszard.cierpiszewski@ue.poznan.pl (R.C.); \\ zenon.foltynowicz@ue.poznan.pl (Z.F.) \\ * Correspondence: marta.ligaj@ue.poznan.pl
}

Received: 29 December 2019; Accepted: 6 February 2020; Published: 9 February 2020

\begin{abstract}
The main function of food packaging is to maintain food's quality and safety. The use of active packaging, including antimicrobial materials, can significantly extend the shelf life of food. Many of these packaging solutions are based on the application of polymer films containing metal nanoparticles (e.g., $\mathrm{Ag}, \mathrm{Au}, \mathrm{Cu}$ ) or metal oxides (e.g., $\mathrm{TiO}_{2}, \mathrm{ZnO}, \mathrm{MgO}$ ). However, the use of iron nanoparticles is rarely mentioned. In the study, polylactide (PLA) films containing zero-valent iron (ZVI) were made by casting method. Pure PLA films and PLA films with the addition of $\mathrm{Fe}_{2} \mathrm{O}_{3}$ were used as comparative materials. The composition and structure of ZVI/PLA films were evaluated with scanning electron microscopy. The XRD spectra performed on ZVI/PLA films confirmed the presence of iron in the packaging material and revealed their oxide form $\left(\mathrm{Fe}_{2} \mathrm{O}_{3}\right)$. The addition of zero-valent iron in the concentration $1 \%, 3 \%$, or $5 \%$ resulted in the formation of crystallographic planes measuring 40.8, 33.6, and $28.6 \mathrm{~nm}$, respectively. The color and gloss of the films, and their antimicrobial activity against bacteria (Bacillus subtilis, Escherichia coli, Staphylococcus epidermidis) and fungi (Geotrichum candidum, Rhodotorula rubra) were also examined. The PLA films with addition of $3 \%$ of ZVI $(w / w)$ inhibited the growth of all tested organisms in contrast to PLA and PLA/ $/ \mathrm{Fe}_{2} \mathrm{O}_{3}$ films. The addition of ZVI to polymer matrix caused changes in its appearance and optical properties. The ZVI/PLA coating used on polyolefin film allowed to extend the shelf life of goat cheese packed in examined material to 6 weeks. Considering the antimicrobial properties of the ZVI/PLA films and PLA biodegradability the obtained material can be successfully applied in the food industry.
\end{abstract}

Keywords: active packaging; zero-valent iron; antimicrobial coating; food packaging

\section{Introduction}

The basic functions of food packaging are closely linked to their role in ensuring food quality and safety in the supply chain and during the storage of groceries by consumers [1]. Commonly used conventional forms of packaging ensure, above all, the protection of packed products, provide information about them and also enable their convenient consumption [2,3]. The protection against adverse external factors, chemical, and/or microbiological pollution mainly results from the barrier properties of packaging materials and the design of the packaging itself, but those are provided in a passive way [4]. Active packaging and materials actively contribute to reducing the effects of the above-mentioned adverse factors and increase the functionality of conventional packaging systems most often by releasing the desired or absorbing harmful substances from the packed product and/or its environment $[4,5]$. The use of active packaging solutions can significantly extend the shelf life of food and reduce the costs associated with protecting food against spoilage as well as disposal of already wasted products. Active packaging is particularly useful for perishable food products such as 
dairy products, fresh meat, fish, or seafood. They can support food protection in the supply chain and enable the reduction of food processing or the use of food preservatives. The most commonly used active packaging solutions include moisture absorbers, oxygen scavengers, carbon dioxide emitters, antioxidant, or antimicrobial factors [1,5-7].

Food is usually a very good environment for the development of various microorganisms, whose existence leads to or accelerates changes in the taste, aroma, appearance, and texture of food products and thus significantly shortens their shelf life. Sometimes contamination of food with pathogenic microorganisms can also pose a threat to the health or life of consumers [8,9]. Antimicrobial active packaging materials are usually designed to lengthen the adaptation phase (lag phase) and limit the further growth of unwanted microorganisms. Packaging materials with active non-volatile substances must have direct contact with the food being protected, for example by using antimicrobial coatings on the internal surface of packaging [10]. In this case, antimicrobial substances may be immobilized on the surface of the active packaging or be released directly from it into the protected product [11]. Antimicrobial coatings and direct packaging wrappers are particularly effective against microorganisms growing on the surface of microbiologically contaminated food products [12]. The active substances used in antimicrobial packaging encompass natural essential oils [13], enzymes and bacteriocins [14], silver zeolites [15], polymeric substances with antimicrobial properties [16], organic acids and their derivatives [17], as well as other substances in nanoparticle size [18-21]. Table 1 presents some examples of commercially available antimicrobial active packaging [1].

Table 1. Examples of commercially available antimicrobial packaging for food.

\begin{tabular}{ccc}
\hline Form of Antimicrobial Packaging & Active Substance(s) & Product Name (Company) \\
\hline Antifungal coatings & Natamycin & Sanico ${ }^{\circledR}$ (Laboratories STANDA) \\
Component for a wrap/packaging foil & Silver & Bactiblock ${ }^{\circledR}$ (NanoBio Maters) \\
Component for a wrap/packaging foil & Silver & Irgaguard ${ }^{\circledR}$ (BASF) \\
Foils, wraps, cardboard packaging & Silver & Novaron ${ }^{\circledR}$ (Taogosei) \\
Foils, wraps, cardboard packaging & Silver zeolites & Aglon ${ }^{\circledR}$ (Aglon Technologies) \\
Foils, multi-layer materials & Inorganic components & Sanic Films ${ }^{\circledR}$ (Nanopack \\
Laminated pads, packaging sheets & Sulphur dioxide & Techology \& Packaging) \\
Sachets & Glucose oxidase & Bioka (Bioka Ltd.) \\
Sachets, foils, wraps & Chlorine dioxide & Microgardie TM $^{\mathrm{TM}}$, Microsphere \\
Sheets & (Bernard Technologies) \\
and antifungal properties & Wasaouro ${ }^{\circledR}$ sheets \\
Shels and foils with antibacterial & Allyl isothiocyanate & (Mitsubishi-Kagagu Foods Co.) \\
\hline
\end{tabular}

Source: Own work.

Many active packaging films are based on antimicrobial properties of nanostructured metal compounds such as silver, gold, and copper nanoparticles [22]. Materials that can be used to make nanocomposites (e.g., metal nanooxides $\mathrm{TiO}_{2}, \mathrm{ZnO}, \mathrm{MgO}$ ) are also tested for antimicrobial properties [23]. Antimicrobial properties of polylactide packaging films are also investigated by applying coatings containing bioactive substances and depositing them onto paper surfaces. The resulting composite materials have strong antibacterial effect against the pathogenic Escherichia coli strains and Listeria monocytogenes. Active films can be used as antibacterial and barrier UV material for food packaging and biomedical applications [24]. In the literature of packaging studies, many antibacterial aspects of nanoparticles have been reported [25] e.g., the soft white cheese was packaged with the chitosan-PVA-TiO $\mathrm{Tilms}_{2}$ and stored at $7{ }^{\circ} \mathrm{C}$ for 30 days. The addition of $\mathrm{TiO}_{2}$ nanoparticles $(2-8 \%)$ into polymer matrix resulted in the decrease of the total bacterial and fungi microflora and the increase of storage period in comparison to a control sample [26]. Similar results were presented for chitosan/carboxymethyl cellulose/ZnO nanoparticles films [27].

The literature on the use of metal nanoparticles with antimicrobial activity in packaging rarely mentions iron nanoparticles. Some reports refer to the application of iron nanoparticles but from the strictly chemical point of view, they are usually iron oxides. Iron nanoparticles, especially zero-valent 
iron, are used as innovative active ingredients in oxygen scavengers for packaging and usually the application is protected by patent law [28]. However, in literature, there can be found descriptions of the potential bactericidal effect of nano- $\mathrm{Fe}^{0}$ on Escherichia coli. It has been found that the bactericidal effect is dependent on the size and specific properties of the nano- $\mathrm{Fe}^{0}$. A significant increase in antimicrobial activity was also observed in the absence of oxygen [29]. The activity of nano-ZVI (nZVI) against Bacillus subtilis, Pseudomonas fluorescens, and Aspergillus versicolor was also studied. The antimicrobial effect of nZVI was demonstrated in both bacterial strains, however, Gram-negative bacteria (P. fluorescens) was less resistant than Gram-positive one (B. subtilis) [30]. The safety of the application of ferrous iron and especially nano-compounds of ZVI, in packaging materials, is also the subject of many discussions [31-33]. No harmful effects of iron on human organisms were found, even nano-iron supplements are used to thread anemia [34-36]. Their beneficial effect on iron deficiency anemia occurs at doses from $3 \mathrm{mg}$ to $6 \mathrm{mg}$ per kilogram of body weight per day. Adverse effects occur at doses above $10-20 \mathrm{mg} / \mathrm{kg}$ of elemental iron. Additionally, the bioavailability of nano-iron depends on the particle size and increases with the reduction of their size-nanoparticles are recognized as a toxicological hazard when their size is of less than $54 \mathrm{~nm}$ [36]. The specific migration of nano-iron from the packaging materials to packed products was investigated by Hamilton Company using composite oxygen scavengers based on nano-iron. Not even minimal iron migration from nano-iron contained in the cross-linked silicone matrix to model substances was observed [28]. Nevertheless, ZVI modified bentonite [37] and kaolinite [38] were approved by the European Food Safety Authority (EFSA) as non-nanoform species applicable in food packaging materials [39,40].

The aim of this work was to examine the impact of the nano-compounds of zero-valent iron additive on selected properties of PLA film and investigate the antimicrobial activity of performed packaging material. The PLA coating with $3 \%$ addition of ZVI $(w / w)$ was applied on polyolefin film. The obtained film was used to pack the bio food product (goat cheese) to evaluate its antimicrobial activity, which has crucial impact on the possibility of extending the shelf life of the packaged product.

\section{Materials and Methods}

\subsection{Materials}

Commercial poly(lactic acid) (PLA) Ingeo ${ }^{\text {TM }}$ 4043D (NatureWorks LLC, Minnetonka, MN, USA) donated by Folpack was used to prepare PLA film. Chloroform was purchased from Sigma Aldrich. The zero-valent iron (ZVI) was prepared in accordance with the method developed in our laboratory and protected by international patents: PCT/PL2011/050055 [41] and EP2658666A1 [42]. The activity of ZVI was described previously [43].

Ethyl alcohol (96\% pure) was purchased from POCH/Avantor Performance Materials (Poland). Nutrient broth (PS 90), Plate Count Agar (PCA) (LAB-AGAR ${ }^{\mathrm{TM}}$, PS 37) and Sabouraud Dextrose with Chloramphenicol LAB-AGAR (PS 146) were provided by BioMaxima (Lublin, Poland). The antimicrobial activity of ZVI/PLA was evaluated against selected microorganisms: Gram-negative bacteria Escherichia coli (ATCC 11775), Gram-positive bacteria Bacillus subtilis (ATCC 11774) and Staphylococcus epidermidis (ATCC 49134), yeast Rhodotorula rubra, and fungus Geotrichum candidum from the research collection of the Poznan University of Life Sciences, Poland.

\subsection{Preparation of Active PLA Film}

Polylactide film containing ZVI was obtained by casting a mixture of PLA and ZVI in chloroform on polished steel form, followed by a uniform distribution of the mixture using a steel plate with a slot milled along the base. The slot was $0.4 \mathrm{~mm}$ high and $100 \mathrm{~mm}$ long. After spreading the mixture, it was allowed to dry at room temperature for $48 \mathrm{~h}$. The initial PLA solution in chloroform was obtained by mixing $10 \mathrm{~g}$ of PLA and $135 \mathrm{~g}$ of chloroform using magnetic stirrer. In order to prevent the evaporation of chloroform, the beaker was covered with watch glass. Mixing was carried out at room temperature for about $3 \mathrm{~h}$. After the complete dissolution of PLA, the magnetic stir bar was removed from the 
beaker and the appropriate portion of ZVI was added $-0.10 \mathrm{~g}, 0.30 \mathrm{~g}$, or $0.50 \mathrm{~g}$ of ZVI per $10 \mathrm{~g}$ of PLA. As a result, the films containing $1 \%, 3 \%$, or $5 \%$ of ZVI were obtained. Before casting onto the form, the whole mixture was mixed for $10 \mathrm{~min}$ in an ice-water bath using the VCX130 ultrasonic homogenizer, Sonics \& Materials Inc, Newtown, CT, USA (frequency: $20 \mathrm{kHz}$, vibration amplitude $50 \%$ ). The obtained ZVI/PLA films had thickness in the range of 50-90 $\mu \mathrm{m}$. The thickness of each film was measured at ten different points with the use of Sylvac S229 digital indicator (Sylvac SA, Yverdon-les-Bains, Switzerland) with a resolution of $0.001 \mathrm{~mm}$. For further tests, films with a standard deviation of sample thickness not exceeding $10 \mu \mathrm{m}$ were used. The ZVI/PLA coating with a $3 \%$ addition of zero-valent iron was used to cover a polyolefin film $(15 \mu \mathrm{m}$ thick, Politerm SF, Centropack, Łódź, Poland). The procedure was the same as described above for casting the mixture of PLA and ZVI in chloroform, but the metal form was replaced with the backing polyolefin film.

\subsection{Elemental Composition Assessment}

The presence of iron on the surface of the PLA film, as well as the determination of its forms, was carried out by X-ray elemental composition assessment. For structure and phase identification, the XRD Panalytical Empyrean with the $\mathrm{CuK} \alpha$ radiation $(45 \mathrm{mV}, 40 \mathrm{~mA})$ was used. The materials were investigated within a $30-120^{\circ} 2 \theta$ range. The Highscore software with the ICDD database was used for phase identification. The microstructure and Fe distribution in samples were investigated by scanning electron microscopy (SEM, Vega Tescan 5135) connected with energy dispersive spectroscopy (EDS, PGT Prism 200 Avalon).

\subsection{Color and Gloss Testing}

The optical parameters of PLA films, with and without ZVI, were evaluated by color measurements of the analyzed films and gloss assessment of their surface. The color measurements of the PLA films were performed on a white background with the application of CR 400 Chroma Meter (Konica Minolta) in CIE L*a*b* color system (illuminating/viewing system conforms to JIS Z 8722 condition c standard). Each film was measured ten times in different places in the distance of at least 10 millimeters from the sample edge. The color change was measured using TCD parameter i.e., Total Color Difference (known also as $\Delta \mathrm{E}$ ), that was calculated in accordance with the following Equation (1) [44]:

$$
\text { TCD value }=\left[(\Delta L)^{2}+(\Delta a)^{2}+(\Delta b)^{2}\right]^{1 / 2}
$$

where $\Delta L, \Delta a$, and $\Delta b$ are differences in $\mathrm{L}$, a and b parameters, respectively, between the color description in CIE L*a*b* for compared colorimetric characteristics-for example in the reference to the color of white background. The TCD values correspond to the specific optical sensations of the observer [44]:

$0<\mathrm{TCD}<1$-observer does not notice the difference in color;

$1<\mathrm{TCD}<2-$ only experienced observer can notice the difference in color;

$2<\mathrm{TCD}<3.5$-inexperienced observer can also notice the difference;

$3.5<$ TCD $<5$-clear difference in color is observable;

$5<$ TCD—observer notices two different colors of the analyzed sample.

The gloss measurements were performed on the surface of analyzed PLA films (with or without ZVI) by TestAn DT-268 gloss meter (PCE Instruments Ltd., Hampshire, UK) at the angle of 60 degrees typical for medium gloss coatings.

The measurements were repeated ten times for each analyzed film placed on a white background both for color and gloss testing. Statistical analysis was performed with Origin 2017 software (OriginLab, Northampton, MA, USA). The results obtained for the separate films were analyzed for the difference significance in $t$-Test for means with the significance level of 0.05 . Superscript letters for significant differences were introduced. The results obtained for individual parameters of tested films, the difference of which was not statistically significant, had the same superscripts. Standard deviation 
was determined for each tested material and its value was used to calculate the standard uncertainty of TCD indexes and gloss measurement results obtained for each analyzed film. The linear fit analyses were performed to describe the relations between the concentration of ZVI introduced into PLA matrix and the change of ZVI/PLA film color (TCD) or its gloss, respectively. $R^{2}$ coefficient were estimated for both relations.

\subsection{Evaluation of the Antimicrobial Activity of ZVI and Application of Active Films}

Antimicrobial activities of PLA films with the addition of ZVI were analyzed in the following steps. The ZVI/PLA films containing $1 \%$ or $3 \%$ addition of ZVI were disinfected by the immersion in $70 \%$ ethanol for $15 \mathrm{~min}$, then they were transferred to sterile Petri dishes and allowed to evaporate the alcohol. Microbial cultures were made on the solid media: nutrient agar (for bacteria-B. subtilis, E. coli, S. epidermidis) and Sabouraud's medium (for fungi-G. candidum, R. rubra). Inoculation was carried out by surface method: $100 \mu \mathrm{L}$ of microbial suspension with a density of $1.5 \times 10^{7}$ cells per $1 \mathrm{~mL}$ (bacteria) or $1 \times 10^{6}$ (fungi) were inoculated onto the solid medium, then the tested films previously dipped in microbial suspension were applied to the medium. The cultures were incubated at $37^{\circ} \mathrm{C} \pm 2{ }^{\circ} \mathrm{C}$ for 24-48 $\mathrm{h}$ (bacteria) and at room temperature for 72-96 $\mathrm{h}$ (fungi). After incubation the inhibition of the microorganisms' growth in the area of direct contact with the tested film (also on the surface of the film) was observed. The results were compared with the intensity of culture growth on the other part of the plate (not contacted with the film).

The antimicrobial activity of ZVI/PLA coating was evaluated by the application of PLA film with $3 \%$ ZVI content on the surface of polyolefin film in accordance with the procedure described in Section 2.2. The film with ZVI/PLA coating was used to prepare functional packaging for a perishable dairy product with a unit weight of $150 \mathrm{~g}$. Uniform portions of fresh goat curd were wrapped in the tested film containing on its inner side a ZVI/PLA coating (in direct contact with the product). The packed product was stored in a fridge at temperature $\left(4^{\circ} \mathrm{C} \pm 2{ }^{\circ} \mathrm{C}\right)$ for six weeks. As control polyolefin film with PLA coating, without ZVI was used. At the beginning of each week, the microbiological state of the packaging surface, the surface and the inside of the product (packed curd) were evaluated in microbial tests. To determine the number of microorganisms on the surface of the packaging, microorganisms were collected from the area of $25 \mathrm{~cm}^{2}$ with a sterile swab. The swab was transferred to $9 \mathrm{~mL}$ of physiological saline and shaken, then $1 \mathrm{~mL}$ of suspension was inoculated into a sterile plate and flooded with appropriate growth medium. Microbiological contamination of the product surface was determined by the contact method (the agar surface is placed onto the cheese surface for $30 \mathrm{~s}$ ). Whereas, microbes from the product's interior were inoculated by taking $1 \mathrm{~g}$ of curd sample from the inside part of a packed product, transferring it to $9 \mathrm{~mL}$ of physiological saline, shaking, then plating $1 \mathrm{~mL}$ of resulting suspension onto a sterile plate and flooding with the appropriate medium.

During six weeks of the packed curd storage the following microbiological tests were performed:

- determination of psychrophilic microorganisms on the PCA medium (incubation at $20{ }^{\circ} \mathrm{C} \pm 2{ }^{\circ} \mathrm{C}$ for $72 \mathrm{~h}$ );

- determination of fungi on the Sabouraud medium (incubation at $20^{\circ} \mathrm{C} \pm 2{ }^{\circ} \mathrm{C}$ for $5-7$ days).

\section{Results}

\subsection{Composition and Structure of ZVI/PLA Films}

The structure and composition of ZVI/PLA films with the level of ZVI addition from $1 \%$ to $5 \%$ were investigated using SEM, but isolating properties of polymer matrix hindered obtaining satisfactory results without blur effect. The iron mapping with EDS spectroscopy revealed the distribution of Fe nanoparticles in the polymer matrix. The Fe nanoparticles (yellow dots) in ZVI/PLA sample with 1\% $(w / w)$ addition of zero-valent iron are relatively uniformly distributed (Figure 1a), whereas the increase in ZVI concentration to 3\% $(w / w)$ led to higher density and uniformity in Fe nanoparticles distribution 
(Figure $1 b)$. The highest ZVI concentration $(5 \% w / w)$ in analyzed ZVI/PLA films led to the formation of areas with larger Fe particles concentration (Figure 1c).
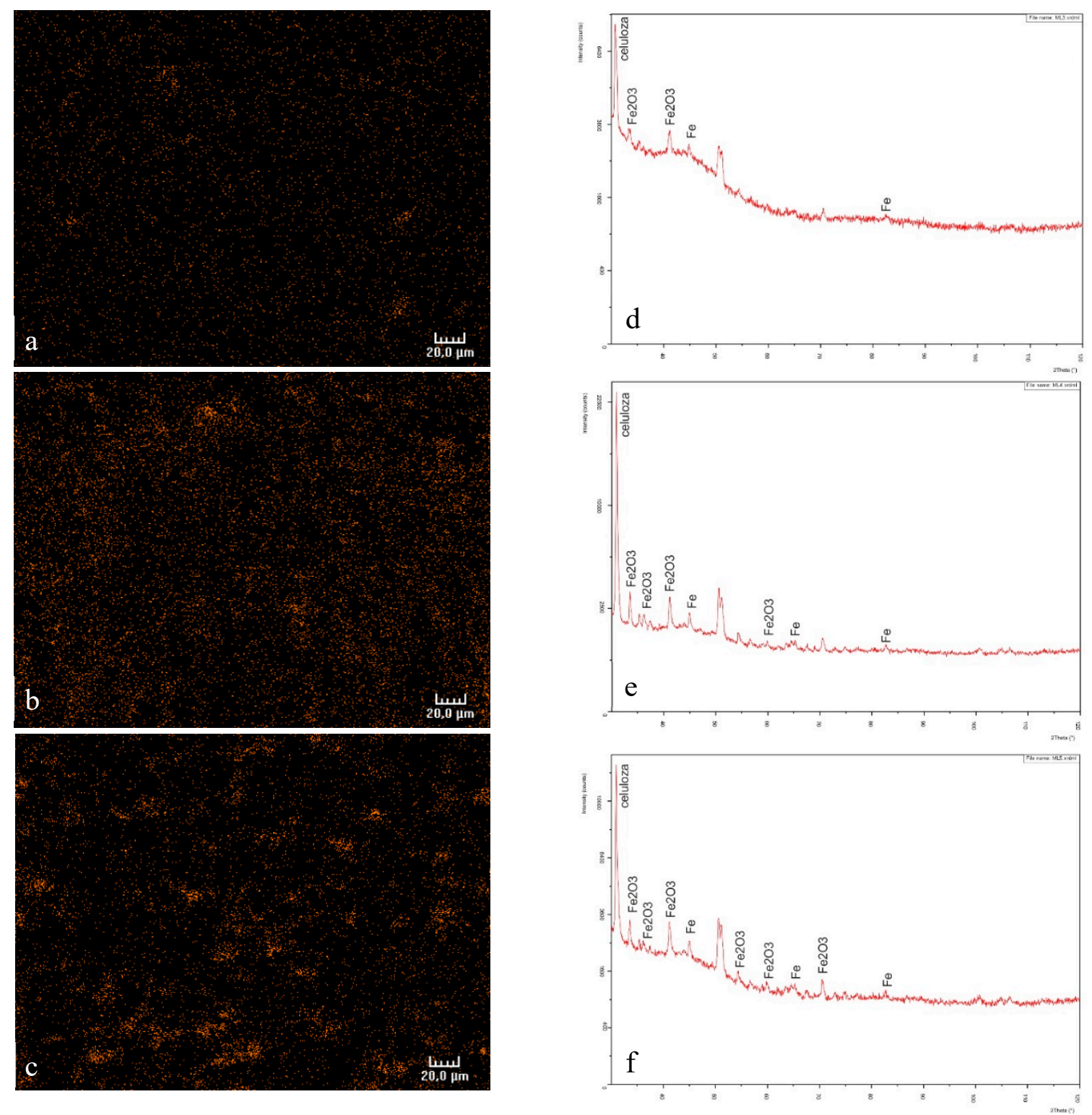

Figure 1. EDS maps of Fe identification on ZVI/PLA films with the addition of $1 \%$ (a), $3 \%$ (b), or $5 \%$ (c) of ZVI, respectively. XRD spectra for ZVI/PLA films with the addition of $1 \%$ (d), $3 \%$ (e), or $5 \%$ (f) of ZVI, respectively.

The XRD spectra performed on ZVI/PLA films with the increasing content of ZVI (Figure 1d-f) confirmed the presence of $\mathrm{Fe}$ in the packaging material and revealed their oxide form $\left(\mathrm{Fe}_{2} \mathrm{O}_{3}\right)$. The $\mathrm{Fe}$ crystallite size was estimated using Sherrer's equation for (110) crystallographic plane. The addition of zero-valent iron into PLA films in concentration $1 \%, 3 \%$, or $5 \%$ led to the formation of crystallographic planes with a size of $40.8,33.6$, and $28.6 \mathrm{~nm}$, respectively. The higher content of ZVI diminished the size of formed metal crystals on the ZVI/PLA surface.

\subsection{Appearance and Optical Properties of ZVI/PLA Films}

The introduction of ZVI into polylactide film changed their optical properties regarding their transparency, color, and gloss. The modification of the appearance of PLA films after the addition of 
$1 \%, 3 \%$, or $5 \%$ of ZVI was evaluated by the colorimetric measurements of the film samples placed on a white background in accordance with the procedure described in paragraph 2.4. The color of white background and film samples were analyzed with CR 400 Chroma Meter in CIE L*a*b* color system. The results obtained for particular PLA films (with or without ZVI addition) and white background are presented in Table 2. The color change of the PLA films (with or without ZVI addition) towards the white background (1) and ZVI/PLA films towards pure PLA film (2) is expressed in TCD values calculated as described above (Section 2.2.) - $\mathrm{TCD}^{1}$ and $\mathrm{TCD}^{2}$, respectively. The small addition of ZVI $(1 \% w / w)$ into the PLA film did not change significantly its transparency (similar values for $\mathrm{L}$ parameter for pure PLA and ZVI (1\%)/PLA) and its color (TCD value close to 1 in the color comparison of ZVI (1\%)/PLA and PLA film).

Table 2. Color parameters (in CIE L*a*b* system) obtained for white background, pure PLA films and PLA with the different addition of ZVI, followed by total color difference index values calculated for the color comparison of PLA and ZVI/PLA films with the color of white background $\left(\mathrm{TCD}^{1}\right)$ and for the comparison of ZVI/PLA with pure PLA films $\left(\mathrm{TCD}^{2}\right)$.

\begin{tabular}{|c|c|c|c|c|c|}
\hline $\begin{array}{l}\text { CIE } L^{*} a^{*} b^{*} \\
\text { Color } \\
\text { Parameters for }\end{array}$ & $\begin{array}{c}\text { White } \\
\text { Background }\end{array}$ & PLA & PLA with $1 \%$ ZVI & $\begin{array}{c}\text { PLA with } 3 \% \\
\text { ZVI }\end{array}$ & $\begin{array}{c}\text { PLA with } 5 \% \\
\text { ZVI }\end{array}$ \\
\hline $\mathrm{L}$ & $96.93 \pm 0.03^{\mathrm{a}}$ & $98.42 \pm 0.15^{b}$ & $97.59 \pm 0.24^{c}$ & $85.31 \pm 2.52^{d}$ & $80.26 \pm 2.53^{\mathrm{e}}$ \\
\hline a & $0.15 \pm 0.02^{\mathrm{f}}$ & $-0.89 \pm 0.03 \mathrm{~g}$ & $-1.00 \pm 0.04 \mathrm{~h}$ & $-0.88 \pm 0.09 \mathrm{~g}$ & $-0.89 \pm 0.08 \mathrm{~g}$ \\
\hline $\mathrm{b}$ & $2.13 \pm 0.02^{\mathrm{i}}$ & $4.79 \pm 0.06^{\mathrm{j}}$ & $5.78 \pm 0.32^{\mathrm{k}}$ & $9.08 \pm 0.41^{1}$ & $8.06 \pm 0.43^{\mathrm{m}}$ \\
\hline \multicolumn{6}{|c|}{ Color change (TCD values) of PLA and ZVI/PLA films rating against a white background } \\
\hline $\mathrm{TCD}^{1}$ & - & $3.22 \pm 0.20$ & $3.88 \pm 0.44$ & $13.58 \pm 2.59$ & $17.73 \pm 2.60$ \\
\hline $\begin{array}{l}\text { Scale of color } \\
\text { change }\end{array}$ & - & $\begin{array}{c}\text { slightly } \\
\text { noticeable }\end{array}$ & slightly noticeable & different color & $\begin{array}{l}\text { very different } \\
\text { color }\end{array}$ \\
\hline \multicolumn{6}{|c|}{ Color change (TCD values) of ZVI/PLA films in relation to PLA film } \\
\hline $\mathrm{TCD}^{2}$ & - & - & $1.30 \pm 0.55$ & $13.79 \pm 2.71$ & $18.45 \pm 2.73$ \\
\hline $\begin{array}{l}\text { Scale of color } \\
\text { change }\end{array}$ & - & - & $\begin{array}{c}\text { unnoticeable/ } \\
\text { slightly noticeable }\end{array}$ & different color & $\begin{array}{l}\text { very different } \\
\text { color }\end{array}$ \\
\hline
\end{tabular}

The increased content of zero-valent iron in ZVI/PLA films caused lower transparency and significant change in color of the film, which is observed in $\mathrm{TCD}^{2}$ values increased proportionally $\left(\mathrm{R}^{2}\right.$ coefficient equaled to 0.935$)$ to the ZVI addition (Figure 2). The ZVI concentration of more than 3\% caused a significant change in PLA color and its transparency.

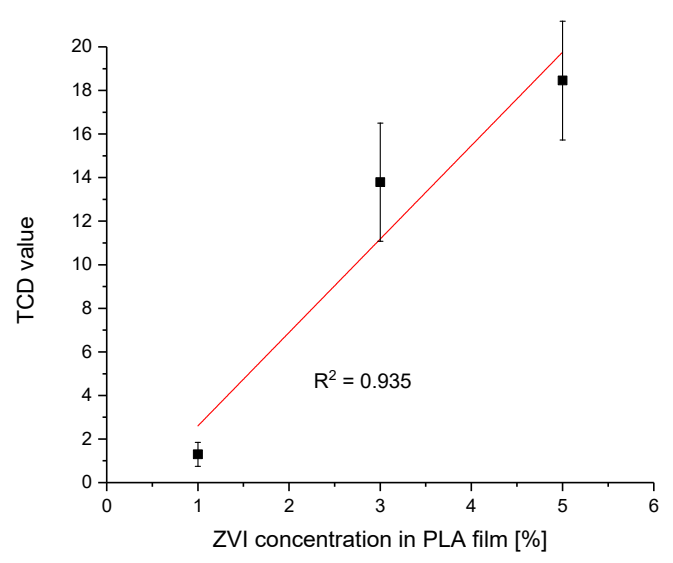

Figure 2. Total color change $\left(\mathrm{TCD}^{2}\right)$ values calculated in the comparison of ZVI/PLA (films with a defined concentration of ZVI) with pure PLA film-the influence of ZVI addition on the color of PLA films. 
The increased addition of zero-valent iron into ZVA/PLA films influenced also their gloss. The comparison of the film gloss at the angle of 60 degrees (typical for medium gloss coatings) revealed a proportional decrease in gloss (with $R^{2}$ coefficient equaled 0.948 ) regarding the concentration of ZVI used for the film preparation (Figure 3). The small amount of ZVI did not influence the gloss of PLA films, but the addition of ZVI above 3\% significantly reduced the gloss of the polylactide film.

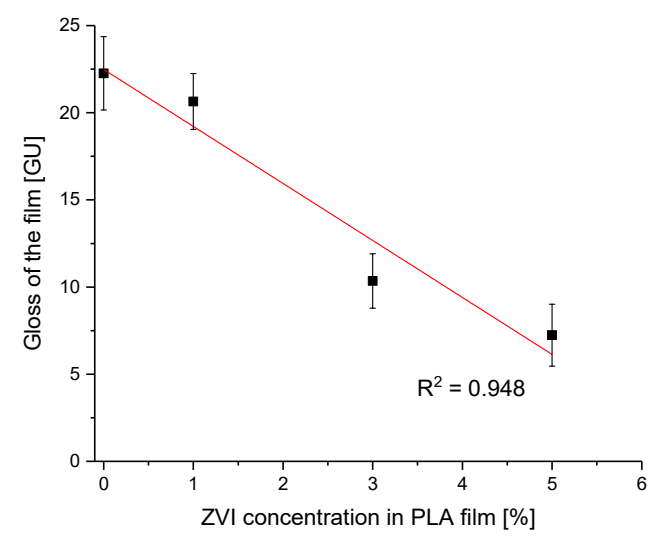

Figure 3. Gloss level of LCA films measured at the angle of 60 degrees for pure polylactide film and with the addition of zero-valent iron in different concentrations.

\subsection{Antimicrobial Properties of ZVI/PLA Films}

The antimicrobial activity of ZVI/PLA films was examined in accordance with the procedure presented in point 2.5. towards the selected group of microorganisms. First, the antimicrobial activity of pure polylactide, PLA with the addition of $3 \%$ iron oxide and $1 \%$ or $3 \%$ of zero-valent iron was checked. All types of PLA films were evaluated against microorganisms from a different group of microbial food contaminants: Gram-negative bacteria (E. coli), Gram-positive bacteria (B. subtilis and S. epidermidis), yeast (R. rubra), and molds (G. candidum). The results of its antimicrobial activity are presented in Table 3. Figure 4 presents microbial culture in Petri dishes illustrating the way of antimicrobial activity recognition of tested materials. The surface of the evaluated films, on which bacteria or yeast grew, was shiny, whereas in the absence of growth, the surface was dull (Figure 4a). The inhibition of fungal growth was observed through the bottom of the Petri dishes with the microbial culture (Figure $4 b$ ).

Table 3. Antimicrobial activity of pure PLA films and PLA films with the addition of iron oxide or ZVI $(3 \% w / w)$ towards selected microorganisms.

\begin{tabular}{ccccc}
\hline $\begin{array}{c}\text { Selected Microorganism/ } \\
\text { PLA Film }\end{array}$ & Pure PLA & PLA + Iron Oxide (3\%) & PLA + ZVI (1\%) & PLA + ZVI (3\%) \\
\hline Geotrichum candidum & - & - & $-/+$ & + \\
\hline Rhodotorula rubra & - & - & $-/+$ & + \\
\hline Staphylococcus epidermidis & - & - & $-/+$ & + \\
\hline Escherichia coli & - & - & $-/+$ & + \\
\hline Bacillus subtilis & - & - & $-/+$ & + \\
\hline "-"-lack of growth inhibition, "-/+"-slight growth inhibition, "+"-growth inhibition.
\end{tabular}

Pure poly(lactic) acid and iron oxide introduced into the PLA film did not reveal antimicrobial activity towards any type of tested microorganism. Zero-valent iron presented antimicrobial activity towards all selected microorganisms but in the case of $1 \% \mathrm{ZVI}$ additive, the growth was inhibited to a very small extent, while the addition of $3 \%$ provided full inhibition of microbial growth in the area of the plate being in direct contact with ZVI/PLA film. Additionally, the microbial growth on the surface of the film containing ZVI additive was also not observed. 
The antimicrobial activity of the ZVI/PLA coating applied onto polyolefin background film was determined by testing the durability of goat cheese wrapped in ZVI/PLA coated films containing 3\% $\mathrm{ZVI}$, because the addition of ZVI in this amount inhibited the growth of reference microbial strains. Coatings with $3 \% \mathrm{ZVI}$ were applied to prepare functional packaging, which was used to wrap goat cream cheese with a unit weight of $150 \mathrm{~g}$. The packaged product was stored at chilled temperature $\left(4{ }^{\circ} \mathrm{C}+/-2{ }^{\circ} \mathrm{C}\right)$ for 6 weeks. During this period, the presence of psychrophilic bacteria and fungi on the surface and inside the cheese, and on the inner surface of the packaging was examined. The cultures were made first 3 days after packing the product, and then every week from the application of the tested package. The preparation of the packed product samples and the evaluation of the antimicrobial activity of ZVI/PLA coatings were described in Section 2.5. The control test consisted of the application of polyolefin foil with PLA coating, but without the addition of ZVI to wrap the goat cheese. The results of goat cream cheese protection with the polyolefin wrapping with internal ZVI/PLA coating are presented in Table 4.

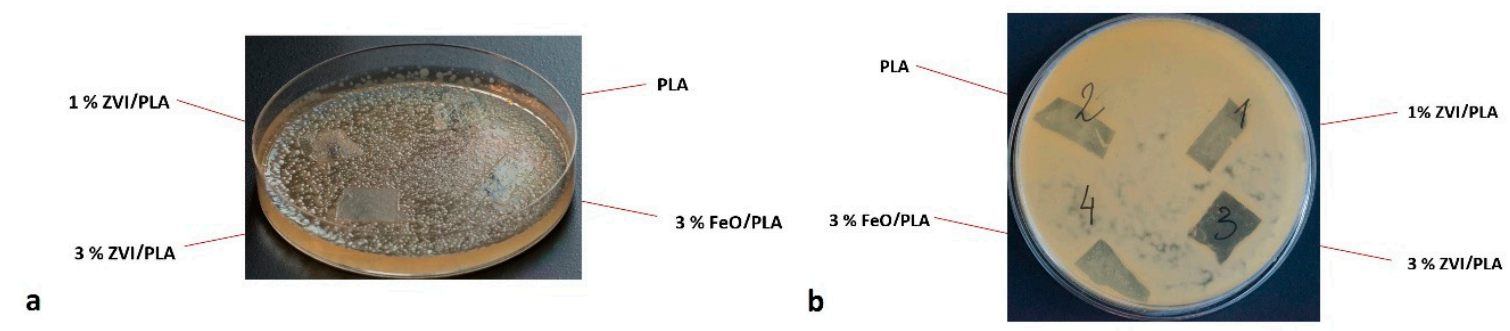

Figure 4. The test of antimicrobial activity of PLA films and PLA films with the addition of ZVI (1 or $3 \%)$, and $\mathrm{FeO}(3 \%)$ against E. coli (a) and G. candidum (b).

Table 4. Antimicrobial activity of polyolefin film with 3\% ZVI/PLA coating applied for wrapping goat cream cheese stored for 6 weeks at chilled temperature.

\begin{tabular}{|c|c|c|c|c|c|c|c|c|}
\hline \multirow[b]{2}{*}{ Type of Packaging } & \multirow{2}{*}{$\begin{array}{l}\text { Analyzed } \\
\text { Microorganisms }\end{array}$} & \multicolumn{7}{|c|}{ Time of Cheese Storage at $4{ }^{\circ} \mathrm{C}+/-2{ }^{\circ} \mathrm{C}$} \\
\hline & & $\begin{array}{c}3 \\
\text { days }\end{array}$ & $\begin{array}{c}1 \\
\text { week }\end{array}$ & $\begin{array}{c}2 \\
\text { weeks }\end{array}$ & $\begin{array}{c}3 \\
\text { weeks }\end{array}$ & $\begin{array}{c}4 \\
\text { weeks }\end{array}$ & $\begin{array}{c}5 \\
\text { weeks }\end{array}$ & $\begin{array}{c}6 \\
\text { weeks }\end{array}$ \\
\hline \multirow{2}{*}{$\begin{array}{l}\text { Polyolefin foil with PLA coating } \\
\text { (packaging inner surface) }\end{array}$} & Bacteria & - & - & + & + & + & + & + \\
\hline & Fungi & - & - & + & + & + & + & + \\
\hline \multirow{2}{*}{$\begin{array}{l}\text { Polyolefin foil with PLA coating } \\
\text { (product surface) }\end{array}$} & Bacteria & - & - & + & + & + & + & + \\
\hline & Fungi & - & - & + & + & + & + & + \\
\hline \multirow{2}{*}{$\begin{array}{l}\text { Polyolefin foil with PLA coating } \\
\text { (product interior) }\end{array}$} & Bacteria & + & + & + & + & + & + & + \\
\hline & Fungi & - & - & - & - & - & + & + \\
\hline \multirow{2}{*}{$\begin{array}{l}\text { Packaging with ZVI/PLA coating } \\
\text { (packaging inner surface) }\end{array}$} & Bacteria & - & - & - & - & - & - & - \\
\hline & Fungi & - & - & - & - & - & - & - \\
\hline \multirow{2}{*}{$\begin{array}{l}\text { Packaging with ZVI/PLA coating } \\
\text { (product surface) }\end{array}$} & Bacteria & - & - & - & - & - & - & - \\
\hline & Fungi & - & - & - & - & - & - & - \\
\hline \multirow{2}{*}{$\begin{array}{l}\text { Packaging with ZVI/PLA coating } \\
\text { (product interior) }\end{array}$} & Bacteria & + & + & + & + & + & + & + \\
\hline & Fungi & - & - & - & - & - & - & - \\
\hline
\end{tabular}

The wrapping made from polyolefin foil with ZVI/PLA coating efficiently protected goat cheese stored at chilled temperature for 6 weeks against the development of psychrophilic bacteria and fungi on the surface of the packed product. The psychrophilic microflora was not present in this storage period, as well as on the inner surface of the packaging made from polyolefin foil coated with the ZVI/PLA layer. The application of tested active packaging material did not influence the presence of natural microflora inside the packed goat cheese, the growth of bacteria derived from product interior was observed. 
Despite the lack of visible microbial contamination of the cheese wrapped in the packaging without ZVI/PLA coating an intensive growth of microorganisms (monitored by cultures on microbiological media) was observed after two weeks of the product storage-both in the case of fungi (Figure 5a,b) and bacteria (Figure 5d,e). The wrapping made from polyolefin foil with ZVI/PLA coating prevented the packed goat curd against the unwanted growth of microorganisms (Figure $5 c, f$ ). On the plates in Figure 5c,f can only be seen small pieces of the cheese transferred during sampling for microbiological testing.

a

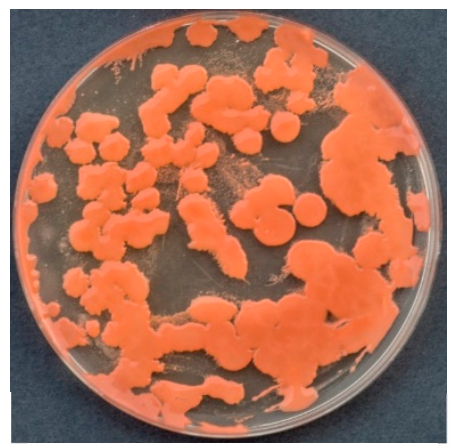

b
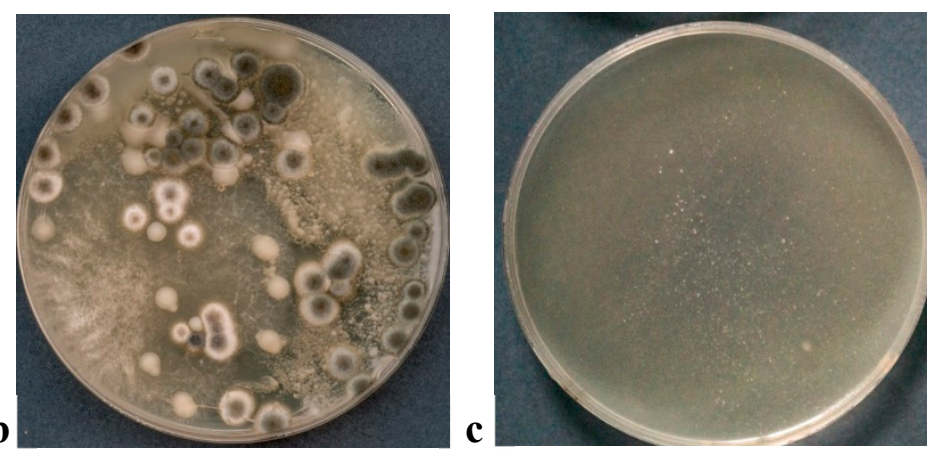

d

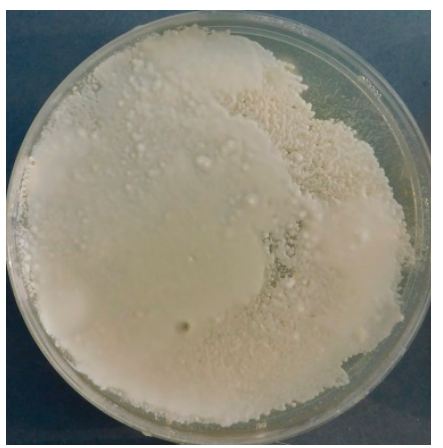

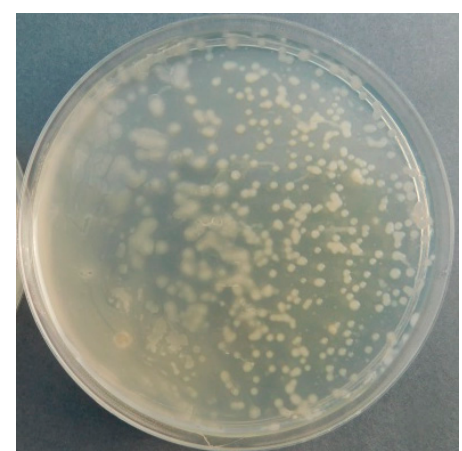

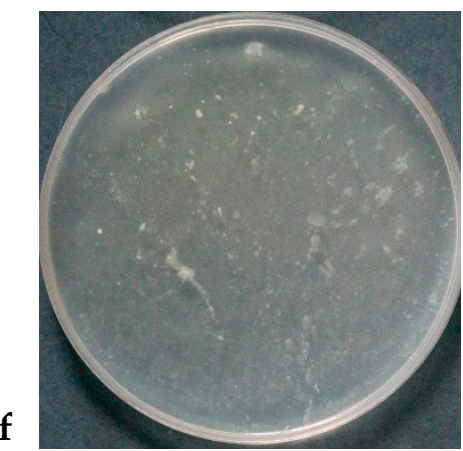

Figure 5. Fungi $(\mathbf{a}-\mathbf{c})$ and psychrophilic bacteria $(\mathbf{d}-\mathbf{f})$ cultured from the inner surface of the packaging of goat curd stored for two weeks at chilled temperature and wrapped in polyolefin foil with PLA coating $(\mathbf{a}, \mathbf{b}, \mathbf{d}, \mathbf{e})$ or polyolefin foil with ZVI/PLA coating $(\mathbf{c}, \mathbf{f})$.

The control polyolefin film with PLA coating, without the addition of ZVI, did not prevent the product against the growth of microorganisms on the surface of packed cheese and on the internal surface of the packaging material, which can be seen in the photos taken for the stored product (Figure 6).

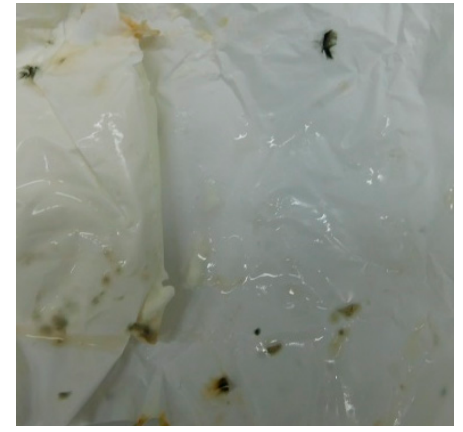

(a)

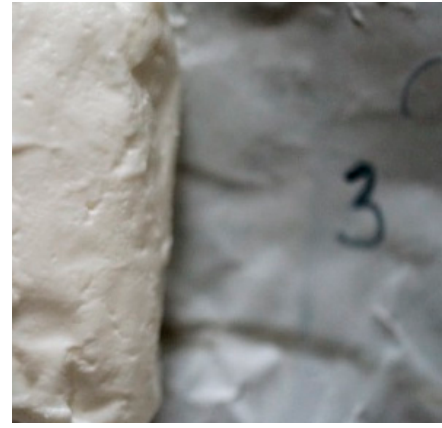

(b)

Figure 6. Goat cream cheese after five-week storage at chilled temperature $\left(4^{\circ} \mathrm{C}+/-2{ }^{\circ} \mathrm{C}\right)$ wrapped in polyolefin foil with PLA coating (a) or polyolefin foil with ZVI/PLA coating (b). 
Microorganisms developed significantly after five-weeks storage of cheese wrapped in packaging without ZVI addition (Figure 6a), while the use of active packaging inhibited the growth of microorganisms both on the surface of the product and the packaging itself (Figure 6b).

\section{Discussion}

Perishable food products require special protection against microbial contamination coming from the environment. Conventional packaging provides a barrier between the packed product and its surroundings, and the durability of the product depends to a large extent on the effectiveness of this protection. Active packaging with antimicrobial properties actively affects the growth of microorganisms inside and/or on the surface of the packed food, and their effectiveness depends on the mechanism of action of the active agent and the way it is introduced into the packaging material. For products containing specific and desirable microflora (e.g., ripening cheese or cottage cheese), the active packaging cannot disturb the development of the above-mentioned microorganisms within the foreseeable shelf-life of the product.

Zero-valent iron was incorporated into polylactide film to provide an active component on the surface of packaging material, which could be applied as a coating for other types of conventional packaging materials such as sheet of paper or plastic film used to wrap food products. The composition and structure of the ZVI/PLA films with different additions of zero-valent iron were evaluated using scanning electron microscopy. Unfortunately, the isolating properties of the polymer matrix did not allow checking the structure of the evaluated material. The energy dispersive spectroscopy was used to confirm the presence of iron in the polymer matrix and to investigate the influence of ZVI concentration on the accessibility of the active compounds in the PLA film. The EDS analysis of ZVI/PLA structure revealed an even distribution of iron nanoparticles over the PLA surface, which is important regarding the effectiveness of the antimicrobial activity of the packaging material. The ZVI concentration of $3 \%$ $(w / w)$ in the PLA matrix provides uniform distribution of active compounds with a high concentration, whereas higher addition of ZVI leads to the formation of iron groups and inefficient application of the active ZVI compounds. The XRD spectra revealed that zero-valent iron incorporated in ZVI/PLA films in the concentration $1 \%, 3 \%$, or $5 \%$, was present in oxide form $\left(\mathrm{Fe}_{2} \mathrm{O}_{3}\right)$ in the planes with the size of $40.8,33.6$, and $28.6 \mathrm{~nm}$, respectively. The higher concentration of ZVI led to the formation of smaller crystallographic planes.

The addition of zero-valent iron compounds into PLA film led to the significant change of its appearance and optical properties. It has been tested in colorimetric and gloss measurements of ZVI/PLA films placed on white background, that even a 3\% addition of ZVI changes the color of the film and its gloss. The color change of PLA films after the addition of zero-valent iron, expressed in TCD values, increases proportionally to the concentration ZVI introduced into a polymer matrix. The $\mathrm{R}^{2}$ coefficient for this relationship was 0.935 . Similarly, the gloss level of ZVI/PLA films measured at the angle of 60 degrees decreased proportionally to the amount of iron introduced into the PLA matrix with the $\mathrm{R}^{2}$ coefficient equal to 0.948 . The introduction of zero-valent iron into polylactide matrix changed significantly its color and gloss, therefore ZVI/PLA films should rather be applied as the coating of the inner part of non-transparent films intended for wrapping food products.

The antimicrobial activity of ZVI/PLA was investigated against selected microorganisms commonly recognized as microbial contamination of dairy products i.e., Gram-negative bacteria (E. coli), Gram-positive ones (B. subtilis and S. epidermidis), yeast (R. rubra), and fungus (G. candidum). The activity of ZVI/PLA films was compared with the influence on the microorganisms' growth on the films made from pure polylactide and from PLA with the addition of $1 \%$ or $3 \%$ iron oxide. Both materials without the addition of zero-valent iron did not influence the growth of all examined microorganisms. The ZVI/PLA film (with the addition of $1 \%$ or $3 \%$ zero-valent iron) inhibited the growth of all tested microorganisms in the direct contact of microbial media and on the film surface, but $1 \%$ concentration of ZVI inhibited only slightly their growth, while 3\% inhibited it completely. The ZVI/PLA film presented activeness in the inhibition of growth of all analyzed microorganisms, but the active agent 
did not migrate into the microbial media, because no microbial growth inhibition zone was observed around the ZVI-containing coating.

With the recent increase in popularity of so-called 'bio' products on the market, which are made from raw materials obtained without the use of chemicals or any other preservatives, it is important that these products should be protected against microbial spoilage through the use of functional packaging $[1,4,11]$. Currently, the products that do not contain preservatives are used mainly by the more demanding group of consumers, but due to their high pro-health value, they are gaining more and more popularity among the general public. Rapid microbial spoilage of these products can contribute to producers' losses, which may discourage them from expanding their product range. The reduced quality associated with the development of an unfavorable microflora may also pose a threat to consumer health $[5,7,10]$. Therefore, coatings based on ZVI active compounds were used to prepare functional packaging, which was applied to pack perishable 'bio' product-goats' cottage cream cheese. The ZVI/PLA coating was deposited on commercially available polyolefin foil, which was used as a reference material to pack the cheese and store it at chilled temperature for 6 weeks. Three days after packing the product, and in each subsequent week, the number of psychrophilic bacteria and the total number of fungi inside the cheese, as well as on the product surface and the packaging were checked. Unfavorable development of bacterial and fungal microflora on the surface of the packed product and on the surface of the packaging was observed after two weeks of storage of the cheese in a conventional film. The packaging made from polyolefin film did not prevent further microbial contamination of the product's interior which was infected by fungi in the fourth week of the cheese storage. The polyolefin film with the ZVI/PLA coating effectively prevented fungal contamination of the inside and the surface of the cheese over the entire six-week storage of the product. Additionally, the active packaging inhibited the growth of psychrophilic bacteria on the surface of the product and packaging material. The ZVI/PLA did not influence on the specific microflora inside the packed goat cottage cheese and could preserve its properties throughout the entire storage period. It turned out that the use of ZVI/PLA coating affected the possibility of extending the shelf life of the cheese to 6 weeks while the product placed in conventional packaging was fit for consumption only within 2 weeks of refrigerated storage.

\section{Conclusions}

Physicochemical and antimicrobial tests of films and coatings made of pure polylactide and PLA with addition of zero-valent iron nanoparticles in the amount of $1 \%, 3 \%$, or $5 \%(w / w)$ were carried out. The incorporation of ZVI nanoparticles into the PLA matrix caused a grayish color change compared to pure PLA in proportion to the ZVI concentration as weel as led to a decrease in the gloss of the ZVI/PLA film. The addition of iron nanoparticles into the PLA caused inhibition of the growth of microorganisms belonging to different groups in terms of morphological structure (Gram-negative and Gram-positive bacteria, yeast, and molds). Complete growth inhibition was observed for ZVI nanoparticles contents above $3 \%(w / w)$ in the PLA matrix. Reference tests performed on pure PLA and PLA containing iron oxide have shown that they do not have the ability to inhibit the growth of any of the tested microorganisms.

Goat cheese wrapped in the packaging foil made of polyolefin with PLA coating containing at the best $3 \%$ of ZVI was stored for 6 weeks in refrigerated condition. During this time no microbial growth was observed on the inner surface of the packaging and on the surface of the product due to the ZVI presence. The prolonged period of cheese shelf life packaged in the developed packaging material with the ZVI/PLA coatings was similar to the results provided in the literature for that of the chitosan-PVA- $\mathrm{TiO}_{2}$ films and chitosan/carboxymethyl cellulose/ZnO nanoparticles films containing the comparable amount of active nanoparticles [26,27]. Additionally, the biodegradable nature of PLA and demonstrated antimicrobial activity the ZVI/PLA films, gives promising prognosis as to their use as active food packaging. 


\section{Patents}

Polish patent application-PL 432267: Packaging material with antimicrobial properties, method of its production and application.

Patent PCT/PL2011/050055, Foltynowicz, Z.; Kozak, W.; Stoinska, J.; Urbanska, M.; Muc, K.; Dominiak, A.; Kublicka, K. Nanoiron-Based Oxygen Scavengers. Uniwersytet Ekonomiczny w Poznaniu. December 2011.

Patent EP2658666, Foltynowicz, Z.; Kozak, W.; Stoinska, J.; Urbanska, M.; Muc, K.; Dominiak, A.; Kublicka, K. Nanoiron-based oxygen scavengers, Uniwersytet Ekonomiczny w Poznaniu. December 2018.

Author Contributions: Conceptualization, M.L., R.C. and Z.F.; data curation, M.L. and M.T.; formal analysis, M.L. and R.C.; investigation, M.L., M.T. and R.C.; methodology, M.L., M.T. and R.C.; project administration, M.L.; resources, M.L., R.C. and Z.F.; software, M.T.; supervision, R.C. and Z.F.; validation, M.L., M.T. and R.C.; visualization, M.L. and M.T.; writing-original draft, M.T.; writing-review \& editing, M.L., M.T., R.C. and Z.F. All authors have read and agreed to the published version of the manuscript.

Funding: This research was funded by Poznan University of Economics and Business, Poland.

Conflicts of Interest: We have no conflicts of interest to disclose.

\section{References}

1. Tichoniuk, M. Innovative packaging improving food quality and extending its shelf life. Pol. J. Commod. Sci. 2019, 1, 21-35. [CrossRef]

2. Vanderroost, M.; Ragaert, P.; Devlieghere, F.; De Meulenaer, B. Intelligent food packaging: The next generation. Trends Food Sci. Techol. 2014, 39, 47-62. [CrossRef]

3. Müller, P.; Schmid, M. Intelligent Packaging in the Food Sector: A Brief Overview. Foods 2019, 8, 16. [CrossRef]

4. Schaefer, D.; Cheung, W.M. Smart Packaging: Opportunities and Challenges. Procedia CIRP 2018, 72, 1022-1027. [CrossRef]

5. Bastarrachea, L.J.; Wong, D.E.; Roman, M.J.; Lin, Z.; Goddard, J.M. Active Packaging Coatings. Coatings 2015, 5, 771-791. [CrossRef]

6. Poyatos-Racionero, E.; Ros-Lis, J.V.; Vivancos, J.L.; Martínez-Máñez, R. Recent advances on intelligent packaging as tools to reduce food waste. J. Clean Prod. 2018, 172, 3398-3409. [CrossRef]

7. Yildirim, S.; Röcker, B.; Pettersen, M.K.; Nilsen-Nygaard, J.; Ayhan, Z.; Rutkaite, R.; Radusin, T.; Suminska, P.; Marcos, B.; Coma, V. Active Packaging Application for Food. Compr. Rev. Food Sci. Food Saf. 2018, 18, 165-199. [CrossRef]

8. Realini, C.E.; Marcos, B. Active and intelligent packaging systems for a modern society. Meat. Sci. 2014, 98, 404-419. [CrossRef]

9. Sofi, S.A.; Singh, J.; Rafiq, S.; Ashraf, U.; Dar, B.N.; Nayik, G.A. A Comprehensive Review on Antibacterial Packaging and its Use in Food Packaging. Curr. Nutr. Food Sci. 2017, 13, 1-8. [CrossRef]

10. Socaciu, M.I.; Semeniuc, C.A.; Vodnar, D.C. Edible Films and Coatings for Fresh Fish Packaging: Focus on Quality Changes and Shelf-life Extension. Coatings 2018, 8, 366. [CrossRef]

11. Malhotra, B.; Keshwani, A.; Kherkwal, H. Antimicrobial food packaging: Potential and pitfalls. Front. Microbiol. 2015, 6, 1-9. [CrossRef]

12. Ramos, M.; Valdés, A.; Beltrán, A.; Garrigós, M.C. Gelatin-Based Films and Coatings for Food Packaging Applications. Coatings 2016, 6, 41. [CrossRef]

13. Atarés, L.; Chiralt, A. Essential oils as additives in biodegradable films and coatings for active food packaging. Trends Food Sci. Technol. 2016, 48, 51-62. [CrossRef]

14. Barbiroli, A.; Bonomi, F.; Capretti, G.; Iametti, S.; Manzoni, M.; Piergiovanni, L.; Rollini, M. Antimicrobial activity of lysozyme and lactoferrin incorporated in cellulose-based food packaging. Food Control 2012, 26, 387-392. [CrossRef]

15. De Araújo, L.O.; Anaya, K.; Castellã Pergher, S.B. Synthesis of Antimicrobial Films Based on Low-Density Polyethylene (LDPE) and Zeolite a Containing Silver. Coatings 2019, 9, 786. [CrossRef] 
16. Soysal, Ç.; Bozkurt, H.; Dirican, E.; Güçlü, M.; Bozhüyük, E.D.; Uslu, A.E.; Kaya, S. Effect of antimicrobial packaging on physicochemical and microbial quality of chicken drumsticks. Food Control 2015, 54, $294-299$. [CrossRef]

17. Júnior, A.V.; Fronza, N.; Bortolini Foralosso, F.; Dezen, D.; Huber, E.; Zimnoch dos Santos, J.H.; Machado, F.R.A.; Novy Quadri, M.G. Biodegradable duo-functional active film: Antioxidant and antimicrobial actions for the conservation of beef. Food Bioprocess Technol. 2015, 8, 75-87. [CrossRef]

18. Cozmuta, A.M.; Peter, A.; Cozmuta, L.M.; Camelia, N.; Crisan, L.; Baia, L.; Turila, A. Active packaging system based on $\mathrm{Ag} / \mathrm{TiO}_{2}$ nanocomposite used for extending the shelf life of bread. Chemical and microbiological investigations. Packag. Technol. Sci. 2014, 28, 271-284. [CrossRef]

19. Mlalila, N.; Kadam, D.M.; Swai, H.; Hilonga, A. Transformation of food packaging from passive to innovative via nanotechnology: Concepts and critiques. J. Food Sci. Technol. 2016, 53, 3395-3407. [CrossRef]

20. Fierascu, I.; Fierascu, I.C.; Dinu-Pirvu, C.E.; Fierascu, R.C.; Anuta, V.; Velescu, B.S.; Jinga, M.; Jinga, V. A Short Overview of Recent Developments on Antimicrobial Coatings Based on Phytosynthesized Metal Nanoparticles. Coatings 2019, 9, 787. [CrossRef]

21. Singh, S.; Gaikward, K.J.; Lee, Y.S. Antimicrobial and antioxidant properties of polyvinyl alcohol bio composite films containing seaweed extracted cellulose nano-crystal and basil leaves extract. Int. J. Biol. Macromol. 2018, 107, 1879-1887. [CrossRef]

22. Hoseinnejad, M.; Jafari, S.M.; Katouzian, I. Inorganic and metal nanoparticles and their antimicrobial activity in food packaging applications. Crit. Rev. Microbiol. 2018, 44, 161-181. [CrossRef]

23. Rhim, J.W.; Park, H.M.; Ha, C.S. Bio-nanocomposites for Food Packaging Applications. Prog. Polym. Sci. 2013, 38, 1629-1652. [CrossRef]

24. Shankar, S.; Wang, L.F.; Rhim, J.W. Incorporation of zinc oxide nanoparticles improved the mechanical, water vapor barrier, UV-light barrier, and antibacterial properties of PLA-based nanocomposite films. Mat. Sci. Eng. C 2018, 93, 289-298. [CrossRef]

25. Jamróz, E.; Kulawik, P.; Kopel, P. The Effect of Nanofillers on the Functional Properties of Biopolymer-Based Films: A Review. Polymers 2019, 11, 675. [CrossRef]

26. Youssef, A.M.; El-Sayed, S.M.; Salama, H.H.; El-Sayed, H.S.; Dufresne, A. Evaluation of bionanocomposites as packaging material on properties of soft white cheese during storage period. Carbohydr. Polym. 2015, 132, 274-285. [CrossRef]

27. Youssef, A.M.; El-Sayed, S.M.; El-Sayed, H.S.; Salama, H.S.; Dufresne, A. Enhancement of Egyptian soft white cheese shelf life using a novel chitosan/carboxymethyl cellulose/zinc oxide bionanocomposite film. Carbohydr. Polym. 2016, 151, 9-19. [CrossRef]

28. Foltynowicz, Z. Nanoiron-Based Composite Oxygen Scavengers for Food Packaging. In Composites Materials for Food Packaging; Cirillo, G., Kozlowski, M.A., Spizzirri, U.G., Eds.; John Wiley \& Sons Inc.: Hoboken, NJ, USA; Scrivener Publishing LLC: Beverly, MA, USA, 2018; pp. 209-234. ISBN 978-1-119-16020-5.

29. Lee, C.; Kim, J.Y.; Lee, W.I.; Nelson, K.L.; Yoon, J.; Sedlak, D.L. Bactericidal Effect of Zero-Valent Iron Nanoparticles on Escherichia coli. Environ. Sci. Technol. 2008, 42, 4927-4933. [CrossRef]

30. Diao, M.; Yao, M. Use of zero-valent iron nanoparticles in inactivating microbes. Water Res. 2009, 43, 5243-5251. [CrossRef]

31. Dunca, T.V. Applications of nanotechnology in food packaging and food safety: Barrier materials, antimicrobials and sensors. J. Colloid Interface Sci. 2011, 363, 1-24. [CrossRef]

32. Llorens, A.; Lloret, E.; Picouet, P.A.; Trbojevich, R.; Fernandez, A. Metallic-based micro and nanocomposites in food contact materials and active food packaging. Trends Food Sci. Technol. 2012, 24, 19-29. [CrossRef]

33. Yan, W.; Lien, H.L.; Koel, B.E.; Zhang, W.X. Iron nanoparticles for environmental clean-up: Recent developments and future outlook. Environ. Sci. Process. Impacts 2013, 15, 63-77. [CrossRef] [PubMed]

34. Theuer, R.C. Iron-fortified infant cereals. Food Rev. Int. 2008, 24, 277-310. [CrossRef]

35. Sekhon, B.S. Food nanotechnology-An overview. Nanotechnol. Sci. Appl. 2010, 3, 1-15.

36. Elsayed, H.H.; Al-Sherbini, A.A.M.; Abd-Elhady, E.E.; El Aziz Ahmed, K.A. Treatment of Anemia Progression via Magnetite and Folate Nanoparticles In Vivo. ISRN Nanotechnol. 2014, 2014, 287575. [CrossRef]

37. Khalaj, M.-J.; Ahmadi, H.; Lesankhosh, R.; Khalaj, G. Study of physical and mechanical properties of polypropylene nanocomposites for food packaging application: Nano-clay modified with iron nanoparticles. Trends Food Sci. Technol. 2016, 51, 41-48. [CrossRef] 
38. Busolo, M.A.; Lagaron, J.M. Oxygen scavenging polyolefin nanocomposite films containing an iron modified kaolinite of interest in active food packaging applications. Innov. Food Sci. Emerg. 2012, 16, 211-217. [CrossRef]

39. EFSA CEF Panel (EFSA Panel on Food Contact Materials, Enzymes, Flavorings and Processing Aids). Scientific Opinion on safety assessment of the active substance, iron (0) modified bentonite as oxygen absorber, for use in active food contact materials. EFSA J. 2013, 11, 3400. [CrossRef]

40. EFSA CEF Panel (EFSA Panel on Food Contact Materials, Enzymes, Flavorings and Processing Aids). Scientific Opinion on safety assessment of the active substance, iron (0) modified kaolinite as oxygen absorber, for use in active food contact materials. EFSA J. 2013, 11, 3401. [CrossRef]

41. Foltynowicz, Z.; Kozak, W.; Stoinska, J.; Urbanska, M.; Muc, K.; Dominiak, A.; Kublicka, K. Nanoiron-Based Oxygen Scavengers. Uniwersytet Ekonomiczny w Poznaniu. PCT/PL Patent 2011/050055, 29 December 2011.

42. Foltynowicz, Z.; Kozak, W.; Stoinska, J.; Urbanska, M.; Muc, K.; Dominiak, A.; Kublicka, K. Nanoiron-based Oxygen Scavengers, Uniwersytet Ekonomiczny w Poznaniu. Patent EP2658666, 19 December 2018.

43. Foltynowicz, Z.; Bardenshtein, B.; Sängerlaub, S.; Antvorskov, H.; Kozak, W. Nanoscale, zero valent iron particles for application as oxygen scavenger in food packaging. Food Packag. Shelf. Life 2017, 11, 74-83. [CrossRef]

44. Mokrzycki, W.; Tatol, M. Color Difference $\Delta$ E-A Survey. Mach. Graph. Vis. 2011, 20, 383-411.

(C) 2020 by the authors. Licensee MDPI, Basel, Switzerland. This article is an open access article distributed under the terms and conditions of the Creative Commons Attribution (CC BY) license (http://creativecommons.org/licenses/by/4.0/). 